\title{
A Density Functional Theory (DFT) Investigation on the Structure and Spectroscopic Behavior of 2-Aminoterephthalic Acid and Its Sodium Salts
}

\author{
Mohammad A. Matin1, Samiran Bhattacharjee1*, Md. Aftab Ali Shaikh2, Tapas Debnath', \\ Mohammed Abdul Aziz ${ }^{3}$
}

${ }^{1}$ Centre for Advanced Research in Sciences (CARS), University of Dhaka, Dhaka, Bangladesh

${ }^{2}$ Department of Chemistry, University of Dhaka, Dhaka, Bangladesh

${ }^{3}$ Department of Theoretical and Computational Chemistry, University of Dhaka, Dhaka, Bangladesh

Email: *s.bhattacharjee@du.ac.bd

How to cite this paper: Matin, M.A., Bhattacharjee, S., Shaikh, M.A.A., Debnath, T. and Aziz, M.A. (2020) A Density Functional Theory (DFT) Investigation on the Structure and Spectroscopic Behavior of 2-Aminoterephthalic Acid and Its Sodium Salts. Green and Sustainable Chemistry, 10, 39-55. https://doi.org/10.4236/gsc.2020.102004

Received: February 4, 2020

Accepted: March 8, 2020

Published: March 11, 2020

Copyright $\odot 2020$ by author(s) and Scientific Research Publishing Inc. This work is licensed under the Creative Commons Attribution-NonCommercial International License (CC BY-NC 4.0). http://creativecommons.org/licenses/by-nc/4.0/ (c) (i) (3) Open Access

\begin{abstract}
As a substitute for lithium ion batteries, $\mathrm{Na}$ chemistry for ion battery systems is promising materials for energy storage applications for the next generation. Herein, the structures, IR and UV-visible spectra of 2-aminoterephthalic acid $\left(\mathrm{H}_{2} \mathrm{ATA}\right)$, disodium 2-aminoterephthalate $\left(\mathrm{Na}_{2} \mathrm{ATA}\right)$, trisodium 2-aminoterephthalate $\left(\mathrm{Na}_{3} \mathrm{ATA}\right)$ and tetrasodium 2-aminoterephthalate $\left(\mathrm{Na}_{4} \mathrm{ATA}\right)$ have been studied using density functional theory (DFT/B3LYP/6-311++G(d,p)). The theoretical geometric parameters and FTIR results showed very good agreement with the experimental results. Different conformers of $\mathrm{Na}_{2} \mathrm{ATA}$, $\mathrm{Na}_{3} \mathrm{ATA}$ and $\mathrm{Na}_{4} \mathrm{ATA}$ showed that the binding energy per sodium in $\mathrm{Na}_{2} \mathrm{ATA}, \mathrm{Na}_{3} \mathrm{ATA}$ and $\mathrm{Na}_{4} \mathrm{ATA}$ is $-694.94,-543.44$ and $-407.46 \mathrm{~kJ} / \mathrm{mol}$, respectively. The $\mathrm{Na}_{3} \mathrm{ATA}$ and $\mathrm{Na}_{4} \mathrm{ATA}$ salts are higher in energy (151.46 and $287.48 \mathrm{~kJ} / \mathrm{mol}$, respectively) than $\mathrm{Na}_{2} \mathrm{ATA}$, indicating the higher stability of the $\mathrm{Na}_{2} \mathrm{ATA}$ complex. The calculated binding energy, enthalpy and Gibbs free energy of $\mathrm{Na}_{2} \mathrm{ATA}, \mathrm{Na}_{3} \mathrm{ATA}$ and $\mathrm{Na}_{4} \mathrm{ATA}$ revealed that the compounds are thermodynamically stable. Natural bond orbital (NBO) analysis of $\mathrm{Na}_{2} \mathrm{ATA}$, $\mathrm{Na}_{3} \mathrm{ATA}$ and $\mathrm{Na}_{4} \mathrm{ATA}$ indicated that the major interaction occurs between the lone pair electrons of the oxygen atom and anti-bonding orbitals of carbon atoms of the two carboxylate ions. UV-visible spectrum of the free $\mathrm{H}_{2} \mathrm{ATA}$ and its sodium salts $\mathrm{Na}_{2} \mathrm{ATA}, \mathrm{Na}_{3} \mathrm{ATA}$ and $\mathrm{Na}_{4} \mathrm{ATA}$ were performed using the time-dependent density functional theory (TD-DFT) method at the level of B3LYP/6-311++G(d,p). The frontier molecular orbital energetic parameters and global reactivity descriptors revealed that the $\mathrm{Na}_{4} \mathrm{ATA}$ and
\end{abstract}


$\mathrm{Na}_{3}$ ATA complexes exhibited a higher band gap $\left(\Delta E_{\text {gap }}\right)$ and electronegativity ( $\chi \mathrm{eV})$ than $\mathrm{Na}_{2} \mathrm{ATA}$.

\section{Keywords}

2-Aminoterephthalic Acid, Sodium 2-Aminoterephthalate, Trisodium

2-Aminoterephthalate, Tetrasodium 2-Aminoterephthalate, Density

Functional Theory

\section{Introduction}

Much attention has recently been paid to the establishment of environmentally friendly more acceptable routes, including removal of toxic reagents, minimization of by-product formation, low cost, green and easy procedure. Batteries play an important role as a power source in our everyday life such as mobile phones, microgrids, satellites, etc. Among the various metal ion batteries, lithium-ion batteries are comparatively mature technology having high energy density, power density and good long cycle life [1], but the high cost and low availability of certain materials are its main disadvantages [2]. Due to low cost and high natural abundance of sodium, the sodium ion batteries (SIBs) have gained much attention in recent years as an economically interesting alternative to lithium ion batteries for the future exploration [2] [3]. Recently, various cathode materials for sodium ion batteries have been studied, viz., olivine-type sodium metal phosphates, prussian blue, $\mathrm{Na}_{3} \mathrm{~V}_{2}\left(\mathrm{PO}_{4}\right)_{3} /$ carbon, Cu-doped $\mathrm{P} 2-\mathrm{Na}_{0.5} \mathrm{Ni}_{0.33} \mathrm{Mn}_{0.67} \mathrm{O}_{2}$ encapsulated with $\mathrm{MgO}$ and titanium substituted P2-Type $\mathrm{Na}_{0.67} \mathrm{Fe}_{0.5} \mathrm{Mn}_{0.5} \mathrm{O}_{2}$ [4]-[9]. For anode materials in SIBs, carbon-based materials (such as graphene, hard carbon, carbon nanosheet and hollow carbon nanospheres), $\mathrm{Na}^{+}$intercalation pseudocapacitance in $\mathrm{TiO}_{2}$ /graphene nanocomposites, amorphous phosphorus/carbon, carbon coated $\mathrm{K}_{0.8} \mathrm{Ti}_{1.73} \mathrm{Li}_{0.27} \mathrm{O}_{4}$ and carbon-coated $\mathrm{NaTi}_{2}\left(\mathrm{PO}_{4}\right)_{3}$ have been investigated [10]-[17]. Nanostructured and nanocomposites of organic conducting polymers have been studied in energy storage areas due to their numerous active sites which can generate green batteries with large capacity, high energy and long cycle life [18] [19] [20] [21]. A group of researchers reported the electrochemical performance of organic tetralithium salts of 2 , 5-dihydroxyterephthalic acid having different morphologies viz., nanosheets, nanoparticles and bulk, as both positive and negative electrode of rechargeable lithium-ion batteries [22]. They observed that nanosheets morphologies exhibited the best electrochemical performance with discharge capacities of 223 and $145 \mathrm{mAh} \cdot \mathrm{g}^{-1}$ at 0.1 and $5 \mathrm{C}$ rates, respectively. Other organic electrode materials, such as, sodium salt of terephthalate and its various derivatives have been used as anode materials in sodium-ion batteries, which were prepared using simple acid-base chemistry [23]. These materials showed outstanding electrochemical activity [24]. In addition, tin, antimony and phosphorus easily formed alloy with 
sodium, which exhibited excellent electrochemical performance as an anode material for Na-ion batteries [24] [25] [26] [27]. Very recently, Li et al. described the sodium-ion storage on $\mathrm{CuS}$ nanosheets anchored into reduced graphene oxide as anode for SIBs [28]. These materials showed high specific capacity, high initial Coulombic efficiency, superior rate performance and excellent long-term cycle stability, suggesting that $\mathrm{Na}$ chemistry for ion battery systems will be feasible for energy storage applications for the next generation. As derivatives of terephthalic acid, the 2-aminoterephthalic acid $\left(\mathrm{H}_{2} \mathrm{ATA}\right)$ have been used for organic building block for assembly of metal-organic framework compounds (for example, isoreticular metal-organic framework-3, IRMOF-3), in which $-\mathrm{NH}_{2}$ groups of organic linker do not involve in the construction of framework structure [29] [30]. Most importantly, this uncoordinated amine group can serve as an active catalyst site for a variety of organic reactions [31] [32] [33] [34] [35] and also show as a selective adsorbent for harmful gases [36]. Karabacak et al. described the experimental and theoretical vibrational and electronic analysis of 2-aminoterephthalic acid [37]. Recently, Renault et al. reported the application of dilithium 2-aminoterephthalate as organic Li-battery anode material [38]. The resulting electrodes showed stable capacities (ca. $180 \mathrm{mAh} \cdot \mathrm{g}^{-1}$ ) and excellent rate capabilities with battery performance at $500 \mathrm{~mA} \cdot \mathrm{g}^{-1}$. The above results encouraged us to carry out the detailed theoretical calculations of 2-aminoterephthalate $\left(\mathrm{H}_{2} \mathrm{ATA}\right)$ and its sodium salts, aim to find out a sustainable, green and low-cost route towards the construction of sodium ion batteries.

In this study, we report the theoretical calculations of $\mathrm{H}_{2} \mathrm{ATA}$, disodium 2-aminoterephthalate $\left(\mathrm{Na}_{2} \mathrm{ATA}\right)$ and its sodium inserted complexes (trisodium 2-aminoterephthalate, $\mathrm{Na}_{3} \mathrm{ATA}$ and tetrasodium 2-aminoterephthalate, $\mathrm{Na}_{4} \mathrm{ATA}$ ) using Density Functional Theory (DFT) with the hybrid B3LYP method to calculate a wide variety of molecular properties such as optimized structure, binding energy $(\Delta \mathrm{E})$ per sodium and spectroscopic properties. NBO (natural bond orbital) analysis and global reactivity descriptors of 2 -aminoterephthalic acid, disodium 2-aminoterephthalate and its inserted sodium complexes $\left(\mathrm{Na}_{3} \mathrm{ATA}\right.$ and $\mathrm{Na}_{4} \mathrm{ATA}$ ) were also performed to evaluate the strength of donor-acceptor interaction energy and chemical reactivity of this compound. Electronic properties and UV-Visible spectra were also calculated. To our knowledge, there has been no systematic theoretical study of 2 -aminoterephthalic acid and its sodium salts using Density Functional Theory (DFT).

\section{Computational Details}

The geometries of the model complexes were optimized at the hybrid B3LYP [39] method based on Becke's three-parameter functional of density functional theory (DFT) calculations using 6-311++G(d,p) basis set. Several structural configurations were considered for comparison of their stability. Geometry optimization was taken to be converged if the maximal atomic force was smaller than 0.00045 hartree/Bohr. Geometries of individual species ligand, metal and met- 
al-complexes were optimized. No geometric constraint was imposed in all the calculations. After optimizing the geometry of each coordination complex, the metal-ligand binding energy $\Delta E$ was calculated as [40].

$$
\Delta E=-\frac{\left(E_{\text {complex }}-E_{\text {metal }}-E_{\text {ligand }}\right)}{n}
$$

where, $E_{\text {complex }}, E_{\text {metal }}$ and $E_{\text {ligand }}$ are the energies of the sodium terephthalate complex, the metal ion and terephthalate ligand, respectively. Therefore, states to the binding energy of the complex per sodium.

The vibrational frequency analyses were performed for all optimized structures (no imaginary frequencies), and indicating that the structures are stable minima on the potential energy surface. It is known that DFT potentials systematically overestimate the vibrational wavenumbers. These discrepancies are corrected either by computing anharmonic corrections explicitly or by introducing a scaled field or by directly scaling the calculated wavenumbers with a proper factor. The raw vibrational frequencies were scaled by a factor of 0.9580 , which produced good agreement with the experiment for a wide range of systems. All calculations were performed using the Gaussian 16 program package [41]. Gauss View 6.0.16 was used for the visualization of the optimized structures and simulated vibrational spectra.

Electronically excited state calculations were performed to examine the UVvisible spectra of the $\mathrm{H}_{2} \mathrm{ATA}$ molecule and its sodium salts. The vertical excitation energies were obtained using the time-dependent density functional theory (TD-DFT) at the level of B3LYP with the $6-311++\mathrm{G}(\mathrm{d}, \mathrm{p})$ basis set, after the ground-state optimization. Molecular orbital analysis was also done to calculate the HOMO-LUMO energy gap. Natural bond orbital analysis was performed to provide the appropriate scheme for the metal-ligand interactions. The global reactivity descriptors were also analyzed to describe the molecular reactivity.

\section{Results and Discussions}

\subsection{Geometry of $\mathrm{H}_{2} \mathrm{ATA}$}

The three different optimized conformers of $\mathrm{H}_{2} \mathrm{ATA}$ together with their energy with respect to the most stable structure are illustrated in Figures 1(a)-(c). Figure 1(a) is the most stable structure with minimum energy conformer where the $\mathrm{C}=\mathrm{O}$ groups are on the same side. The second (Figure 1(b)) and third (Figure $1(c)$ ) conformers are more than 0.76 and $11.81 \mathrm{~kJ} / \mathrm{mol}$, respectively, higher in energy than conformer 1a. The optimized geometrical parameters in both gas phase and different solvents are listed in Table 1. The bond lengths of both $\mathrm{C}-\mathrm{COOH}(1)$ and C-COOH (2) in gas phase are slightly shorter (ca. $0.02 \AA$ ) than experimental results (Table 1) [37]. Due to solvent effects, this bond length decreases almost by $0.018 \AA$ than experimental. The $\mathrm{C}-\mathrm{NH}_{2}$ bond lengths both in gas phase and different solvents are calculated about $0.005 \AA$ shorter than experimental result. There are no significant effects of solvents. Due to Coulombic interaction between $\mathrm{O}$ and $\mathrm{H}$ of $\mathrm{COOH}$ bond, $\mathrm{C}-\mathrm{O}$ bond was calculated larger 
than $\mathrm{C}=\mathrm{O}$ bond. The $\mathrm{C}=\mathrm{O}$ bond is $0.005 \AA$ larger than experimental results and no such significant difference was found in other solvents. The calculated bond angles of two carboxylates are found to be $1.83^{\circ}$ and $1.68^{\circ}$ shorter than experimental results [37]. It is also noticed that the calculated bond angles in different solvents varies by $1.50^{\circ}$ and $1.44^{\circ}$ respectively. These calculated values are good agreements with the experimental results [37] except the $\mathrm{NH}_{2}$ bond angles which are predicted shorter by $1.78^{\circ}$ in gas phase and almost $2.90^{\circ}$ in different solvents.

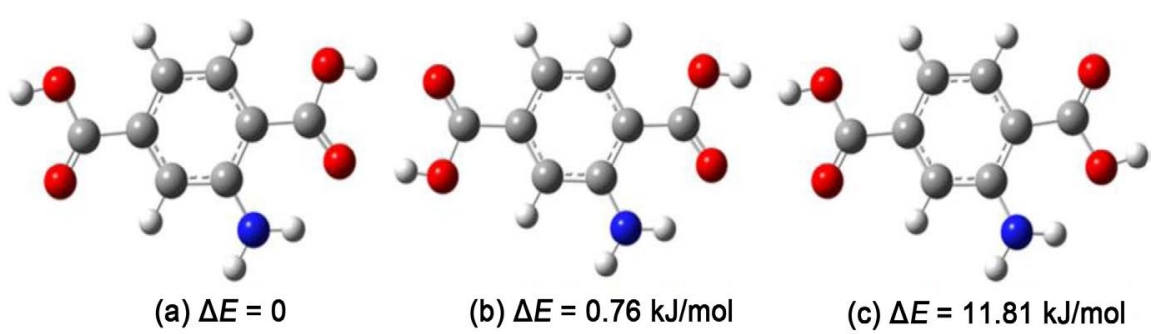

Figure 1. Theoretical optimized minimum energy conformer of the $\mathrm{H}_{2} \mathrm{ATA}$. Grey, white, blue and red circles represent carbon, hydrogen, nitrogen and oxygen, respectively.

Table 1. Comparison of the theoretical (optimized) and experimental geometric parameters of $\mathrm{H}_{2}$ ATA in gas phase and different solvents.

\begin{tabular}{|c|c|c|c|c|c|c|}
\hline \multirow[b]{2}{*}{ Medium $^{\mathrm{a}}$} & \multicolumn{6}{|c|}{ Molecular Geometry ${ }^{\mathrm{b}}$} \\
\hline & $\begin{array}{c}d_{(\mathrm{C}-\mathrm{O})} \\
(\AA)\end{array}$ & $\begin{array}{c}d_{(\mathrm{C}=\mathrm{O})} \\
(\AA)\end{array}$ & $\begin{array}{c}d_{(\mathrm{C}-\mathrm{N})} \\
(\AA)\end{array}$ & $\begin{array}{c}d_{\text {(Cg-C) }} \\
(\AA)\end{array}$ & $\begin{array}{l}\theta_{(\mathrm{COO})} \\
\text { (deg.) }\end{array}$ & $\begin{array}{c}\theta_{\left(\mathrm{NH}_{2}\right)} \\
\text { (deg.) }\end{array}$ \\
\hline \multirow{2}{*}{ Gas } & 1.356 & 1.208 & \multirow{2}{*}{1.361} & 1.469 & 120.47 & \multirow{2}{*}{120.22} \\
\hline & 1.355 & 1.221 & & 1.492 & 122.12 & \\
\hline \multirow{2}{*}{ DMF } & 1.351 & 1.213 & \multirow{2}{*}{1.361} & 1.471 & 120.80 & \multirow{2}{*}{119.10} \\
\hline & 1.348 & 1.223 & & 1.493 & 122.36 & \\
\hline \multirow{2}{*}{ DMSO } & 1.351 & 1.213 & \multirow{2}{*}{1.360} & 1.471 & 120.80 & \multirow{2}{*}{119.10} \\
\hline & 1.348 & 1.223 & & 1.493 & 122.36 & \\
\hline \multirow{2}{*}{$\mathrm{EtOH}$} & 1.352 & 1.212 & \multirow{2}{*}{1.360} & 1.471 & 120.75 & \multirow{2}{*}{119.38} \\
\hline & 1.349 & 1.223 & & 1.492 & 122.31 & \\
\hline \multirow{2}{*}{$\mathrm{EtSH}$} & 1.352 & 1.212 & \multirow{2}{*}{1.360} & 1.471 & 120.75 & \multirow{2}{*}{119.38} \\
\hline & 1.349 & 1.223 & & 1.492 & 122.31 & \\
\hline \multirow{2}{*}{ Pyridine } & 1.351 & 1.213 & \multirow{2}{*}{1.360} & 1.471 & 120.78 & \multirow{2}{*}{119.20} \\
\hline & 1.348 & 1.223 & & 1.493 & 122.34 & \\
\hline \multirow{2}{*}{ FA } & 1.351 & 1.213 & \multirow{2}{*}{1.361} & 1.471 & 120.81 & \multirow{2}{*}{119.07} \\
\hline & 1.347 & 1.223 & & 1.493 & 122.36 & \\
\hline \multirow{2}{*}{ NBA } & 1.353 & 1.212 & \multirow{2}{*}{1.360} & 1.471 & 120.72 & \multirow{2}{*}{119.43} \\
\hline & 1.349 & 1.222 & & 1.492 & 122.29 & \\
\hline \multirow{2}{*}{$\mathrm{ACN}$} & 1.351 & 1.213 & \multirow{2}{*}{1.361} & 1.471 & 120.80 & \multirow{2}{*}{119.11} \\
\hline & 1.347 & 1.223 & & 1.493 & 122.36 & \\
\hline \multirow{2}{*}{ Exper. } & 1.330 & 1.195 & \multirow{2}{*}{1.365} & 1.489 & 122.3 & \multirow{2}{*}{122.0} \\
\hline & 1.333 & 1.216 & & 1.512 & 123.8 & \\
\hline
\end{tabular}

[a] DMF = dimethylformamide, $\mathrm{DMSO}=$ dimethyl sulfoxide, $\mathrm{EtOH}=$ ethanol, $\mathrm{EtSH}=$ ethanethiol, $\mathrm{FA}=$ formamide, NBA = n-butylamine, $\mathrm{ACN}=$ acetonitrile. [b] $d=$ bond length, $d(\mathrm{Cg}-\mathrm{C})=d\left(\mathrm{C}_{\text {ring }}-\mathrm{C}\right), \theta=$ bond angle. 


\subsection{Geometries of Sodium Salts}

The three different optimized structures of disodium 2-aminoterephthalate $\left(\mathrm{Na}_{2}\right.$ ATA), sodium inserted complexes trisodium $\left(\mathrm{Na}_{3} \mathrm{ATA}\right)$ and tetrasodium $\left(\mathrm{Na}_{4}\right.$ ATA) 2-aminoterephthalate were shown in Figures 2-4 and the results were summarized in Table 2. A significant change of bond lengths of C-N and $\mathrm{C}_{\text {ring }}-\mathrm{C}$ were observed in disodium, trisodium and tetrasodium salts of $\mathrm{H}_{2} \mathrm{ATA}$. The $\mathrm{C}-\mathrm{N}$ bond lengths of tetrasodium salt were $0.055 \AA$ larger than disodium salt. A significant change of bond angle of $\mathrm{NH}_{2}$ was observed in disodium and its sodium inserted complexes and about $8.18^{\circ}$ larger in disodium complex compare to trisodium and tetrasodium complex.

Different conformers of the $\mathrm{C}_{8} \mathrm{H}_{5} \mathrm{Na}_{\mathrm{x}} \mathrm{NO}_{4}(\mathrm{x}=2,3$ or 4) were investigated by DFT calculations (Figures 2-4). In the case of $\mathrm{C}_{8} \mathrm{H}_{5} \mathrm{Na}_{2} \mathrm{NO}_{4}$, there is a negligible

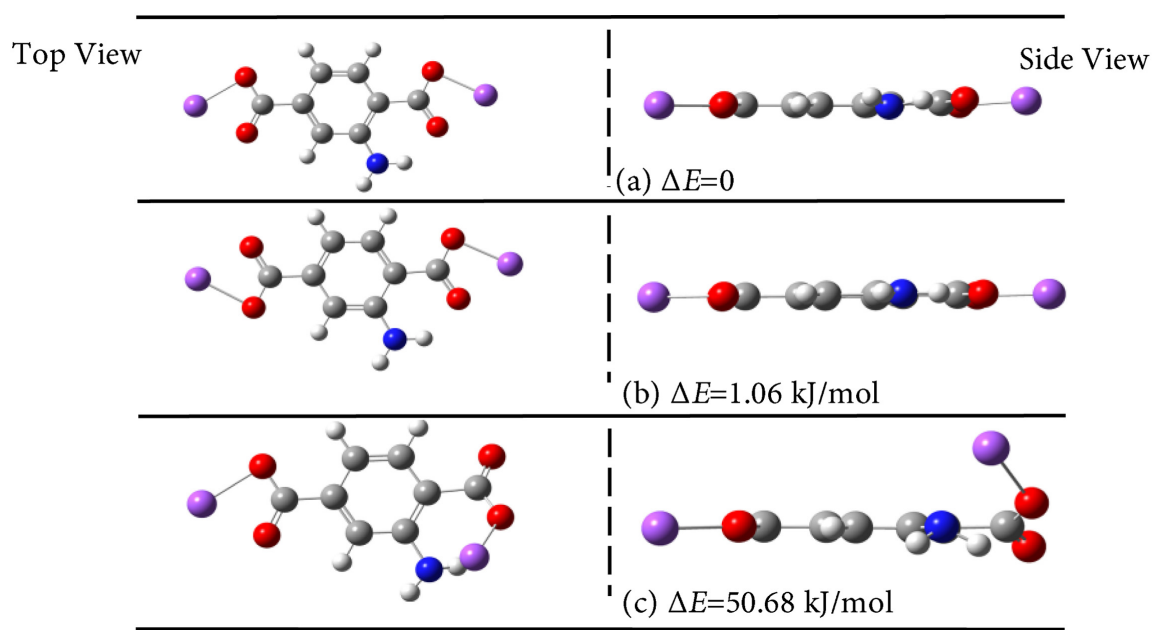

Figure 2. Structures of disodium 2-aminoterephthalate $\left(\mathrm{Na}_{2} \mathrm{ATA}\right)$. The three different conformations of $\mathrm{Na}_{2}$ ATA together with their energy with respect to the most stable structure. Grey, white, blue, red and purple circles represent carbon, hydrogen, nitrogen, oxygen and sodium atoms, respectively.

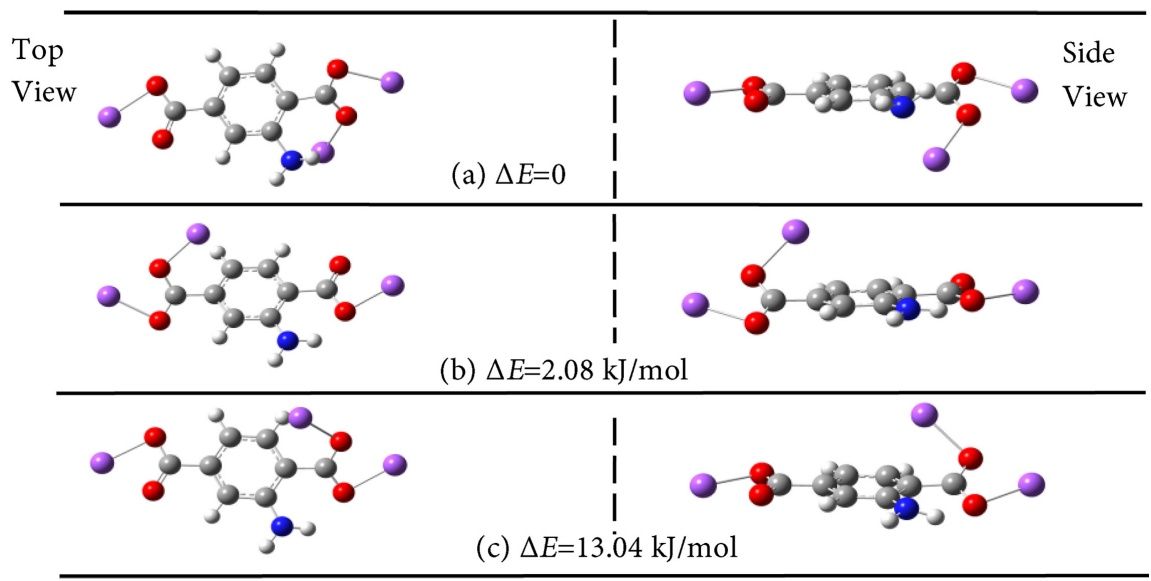

Figure 3. Structures of trisodium 2-aminoterephthalate $\left(\mathrm{Na}_{3} \mathrm{ATA}\right)$. The three different conformations of $\mathrm{Na}_{3} \mathrm{ATA}$ together with their energy with respect to the most stable structure. 


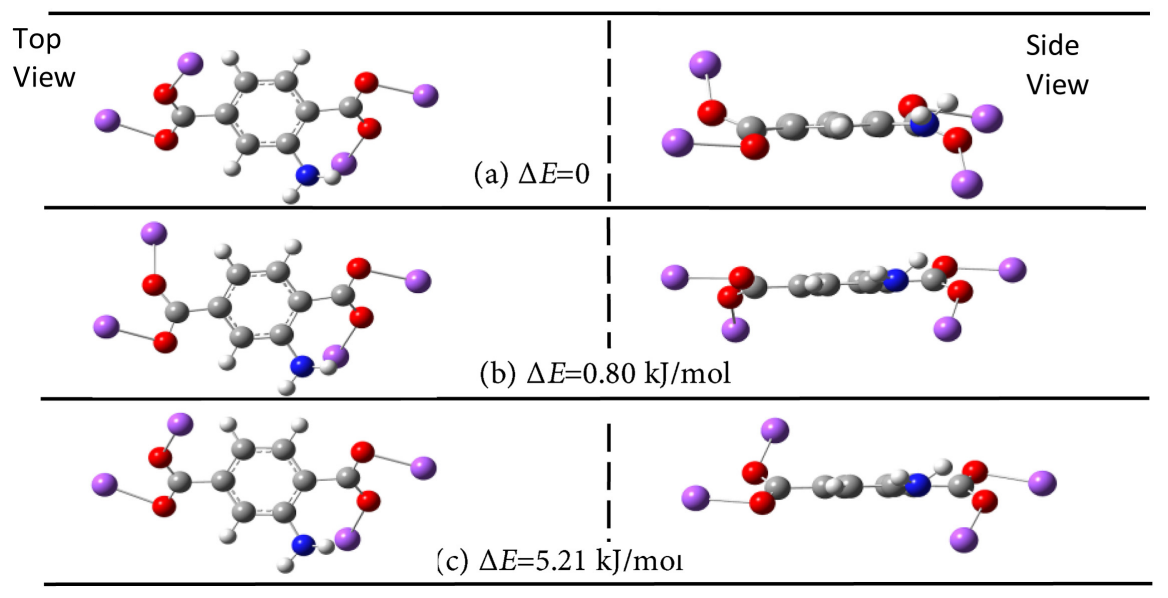

Figure 4. Structures of tetrasodium 2-aminoterephthalate $\left(\mathrm{Na}_{4} \mathrm{ATA}\right)$. The three different conformations of $\mathrm{Na}_{4} \mathrm{ATA}$ together with their energy with respect to the most stable structure.

Table 2. Geometrical parameters of $\mathrm{Na}_{2} \mathrm{ATA}, \mathrm{Na}_{3} \mathrm{ATA}$ and $\mathrm{Na}_{4} \mathrm{ATA}$ (optimized lowest energy structure).

\begin{tabular}{cccccc}
\hline Complex & $d_{\mathrm{C}-0}, \mathrm{~S}(\AA)$ & $d_{\mathrm{C}-\mathrm{N}}^{\prime} \mathrm{S}(\AA)$ & $d_{\mathrm{C}_{\text {ring }}-\mathrm{C}}^{\prime} \mathrm{S}(\AA)$ & $\theta_{\mathrm{CoO}^{\prime}}^{\prime} \mathrm{S} \quad($ deg. $)$ & $\theta_{\mathrm{NH}_{2}}($ deg. $)$ \\
\hline $\mathrm{Na}_{2} \mathrm{ATA}$ & 1.276 & 1.379 & 1.502 & 122.32 & 118.30 \\
$\mathrm{Na}_{3} \mathrm{ATA}$ & 1.268 & 1.438 & 1.509 & 123.17 & 108.32 \\
$\mathrm{Na}_{4} \mathrm{ATA}$ & 1.290 & 1.426 & 1.511 & 122.90 & 108.73 \\
\hline
\end{tabular}

energy difference for the rotation of the carboxylate group in the meta position as compared to the amino group, but a relative increase in energy of $1.06 \mathrm{~kJ} / \mathrm{mol}$ and $50.68 \mathrm{~kJ} / \mathrm{mol}$ if the sodium is placed between the ortho-carboxylate and the amino group (Figure 2(b) and Figure 2(c)). The sodium ion naturally found in the unreduced carboxylate group, whereas retaining the energetically favorable location for one sodium atom near to the amino group.

According to Table 3, the binding energy, enthalpy and Gibbs free energy of $\mathrm{Na}_{2} \mathrm{ATA}$ complex exhibit value on $-694.94,-543.44$ and $-407.46 \mathrm{~kJ} / \mathrm{mol} \mathrm{re}-$ spectively and this suggests the thermodynamically most stability of the complex. The binding energies of $\mathrm{Na}_{3} \mathrm{ATA}$ and $\mathrm{Na}_{4} \mathrm{ATA}$ in the range of -543.44 to $-407.46 \mathrm{~kJ} / \mathrm{mol}$, also suggest the thermodynamical stability. The per sodium energy difference of $\mathrm{Na}_{2} \mathrm{ATA}$ is smaller (151.46 and $287.48 \mathrm{~kJ} / \mathrm{mol}$ ) compare to $\mathrm{Na}_{3} \mathrm{ATA}$ and $\mathrm{Na}_{4} \mathrm{ATA}$, indicating the higher stability of the $\mathrm{Na}_{2} \mathrm{ATA}$ complex. The binding energies, enthalpies and Gibbs free energy of disodium inserted complexes $\left(\mathrm{Na}_{3} \mathrm{ATA}\right.$ and $\left.\mathrm{Na}_{4} \mathrm{ATA}\right)$ are also tabulated in Table 3 .

\subsection{FTIR Spectra}

The calculated infrared (IR) absorption frequencies of the compound and its sodium complexes in gasphase are listed in Table 4 and the spectra are shown in Figure 5. The calculated wavenumbers are scaled by a factor of 0.9580 . The strong bands at 3615 and $3611 \mathrm{~cm}^{-1}$ of free $\mathrm{H}_{2} \mathrm{ATA}$ assigned to $\mathrm{O}-\mathrm{H}$ stretching 
Table 3. Binding energy $(\Delta E)$, enthalpy $(\Delta H)$ and Gibbs free energy $(\Delta G)$ of $\mathrm{Na}_{2} \mathrm{ATA}$, $\mathrm{Na}_{3}$ ATA and $\mathrm{Na}_{4}$ ATA (optimized lowest energy structure).

\begin{tabular}{cccc}
\hline Complex & $\Delta E(\mathrm{~kJ} / \mathrm{mol})$ & $\Delta H(\mathrm{~kJ} / \mathrm{mol})$ & $\Delta G(\mathrm{~kJ} / \mathrm{mol})$ \\
\hline $\mathrm{Na}_{2} \mathrm{ATA}$ & -694.94 & -690.96 & -657.90 \\
$\mathrm{Na}_{3} \mathrm{ATA}$ & -543.44 & -539.73 & -507.15 \\
$\mathrm{Na}_{4} \mathrm{ATA}$ & -407.46 & -404.35 & -372.96 \\
\hline
\end{tabular}

Table 4. Characteristic IR bands $\left(\mathrm{cm}^{-1}\right)$ for $\mathrm{H}_{2} \mathrm{ATA}, \mathrm{Na}_{2} \mathrm{ATA}, \mathrm{Na}_{3} \mathrm{ATa}$ and $\mathrm{Na}_{4} \mathrm{ATA}^{\mathrm{a}}$.

\begin{tabular}{|c|c|c|c|c|c|c|c|c|}
\hline Complex & $v(\mathrm{OH})$ & $v_{\text {asy }}\left(\mathrm{NH}_{2}\right)$ & $v_{s y}\left(\mathrm{NH}_{2}\right)$ & $\downarrow \mathrm{C}=\mathrm{O}$ & $v_{\text {asy }}(\mathrm{C}-\mathrm{O})$ & $v_{\mathrm{sy}}(\mathrm{C}-\mathrm{O})$ & $v(\mathrm{C}=\mathrm{C})$ & $v(\mathrm{C}-\mathrm{N})$ \\
\hline \multirow{2}{*}{$\mathrm{H}_{2}$ ATA } & 3615 & \multirow{2}{*}{3555} & \multirow{2}{*}{3405} & 1711 & \multirow[b]{2}{*}{-} & \multirow[b]{2}{*}{-} & \multirow{2}{*}{1493} & \multirow{2}{*}{1250} \\
\hline & 3611 & & & 1670 & & & & \\
\hline $\mathrm{Na}_{2} \mathrm{ATA}$ & - & 3562 & 3369 & - & 1491 & 1394 & 1584 & 1228 \\
\hline \multirow[t]{2}{*}{$\mathrm{Na}_{3} \mathrm{ATA}$} & & 3534 & 3386 & & 1574 & 1361 & \multirow[t]{2}{*}{1591} & \multirow[t]{2}{*}{1196} \\
\hline & & & & & 1522 & 1342 & & \\
\hline \multirow[t]{2}{*}{$\mathrm{Na}_{4} \mathrm{ATA}$} & \multirow[t]{2}{*}{ - } & \multirow{2}{*}{3529} & \multirow[t]{2}{*}{3392} & \multirow[t]{2}{*}{ - } & 1566 & 1367 & \multirow{2}{*}{1587} & \multirow{2}{*}{1225} \\
\hline & & & & & 1536 & 1336 & & \\
\hline
\end{tabular}

[a] $v=$ stretching vibration, $v_{\text {asy }}=$ asymmetric and $v_{\mathrm{sy}}=$ symmetric.

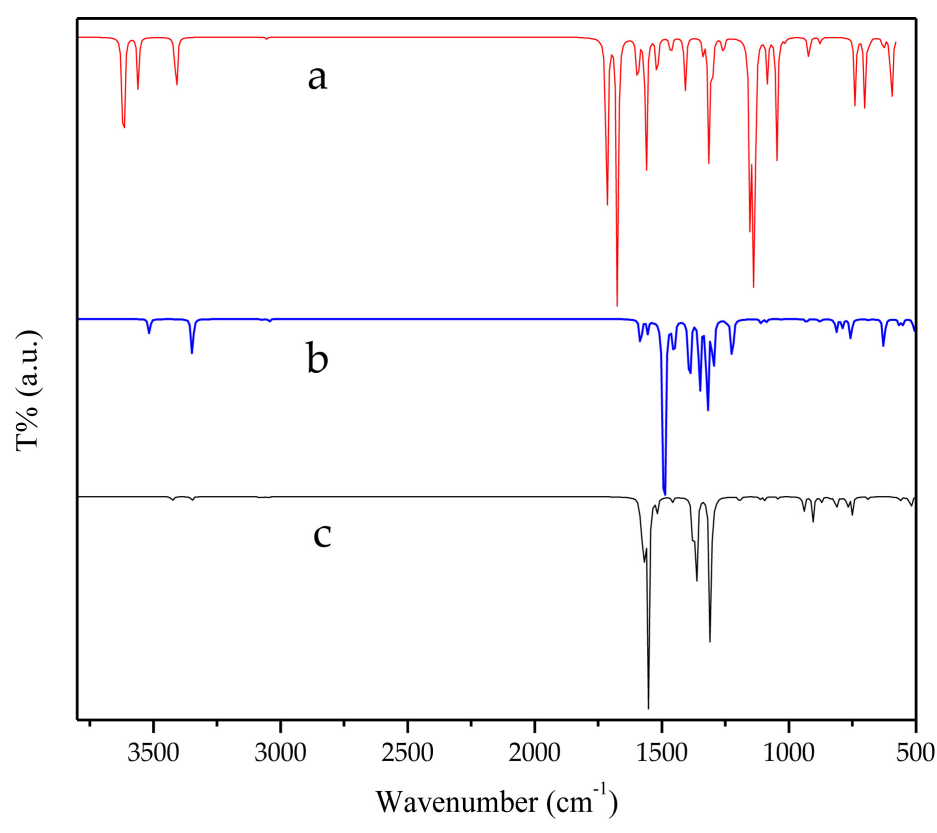

Figure 5. Theoretical IR spectra of (a) free $\mathrm{H}_{2} \mathrm{ATA}$, (b) $\mathrm{Na}_{2} \mathrm{ATA}$ and (c) $\mathrm{Na}_{4}$ ATA.

vibrations of carboxylic groups, were disappeared on metal carboxylate formation [42]. The strong bands at 1711 and $1670 \mathrm{~cm}^{-1}$ of free $\mathrm{H}_{2} \mathrm{ATA}$ in FT-IR due to $\mathrm{C}=\mathrm{O}$ stretching vibration are shifted to 1491 and $1394 \mathrm{~cm}^{-1}$ in the disodium 2 -aminoterephthalate complex, $\mathrm{Na}_{2} \mathrm{ATA}$, correspond to asymmetric $v_{\text {asy }}(\mathrm{C}-\mathrm{O})$ and symmetric $v_{s y}(\mathrm{C}-\mathrm{O})$ vibrations, respectively [43]. On the other hand, both trisodium 
2-aminoterephthalate $\left(\mathrm{Na}_{3} \mathrm{ATA}\right)$ and the tetrasodium 2-aminoterephthalate, $\mathrm{Na}_{4}$ ATA, exhibited four bands at ca.1574 and ca.1522 $\mathrm{cm}^{-1}$, and at ca.1361 andca.1342 $\mathrm{cm}^{-1}$, due to asymmetric $v_{\text {asy }}(\mathrm{C}-\mathrm{O})$ and symmetric $v_{\text {sy }}(\mathrm{C}-\mathrm{O})$ vibrations, respectively (Table 4). The FTIR spectra of $\mathrm{H}_{2} \mathrm{ATA}$ and its sodium salts exhibited two bands at ca. 3550 and ca. $3390 \mathrm{~cm}^{-1}$ due to the amino group [44]. In addition, all compounds showed band at ca. $1230 \mathrm{~cm}^{-1}$ which may be assigned to the C-N stretching vibrations [45].

\subsection{Natural Bond Orbital (NBO) Analysis}

The NBO analysis was known to be effective tools for chemical elucidation of hyperconjugative interaction and electron density transfer from the filled lone pair electron [46]. Density Functional Theory with the hybrid B3LYP method was used for NBO calculation to examine the various second-order interactions between the filled orbitals of one subsystem andunoccupied orbital of another subsystem. NBO analysis of disodium, trisodium and tetrasodium 2-aminoterephthalate was carried out to evaluate the strength of donor-acceptor interaction energy, $\mathrm{E}(2)$ of these complexes and the results are summarized (disodium and tetrasodium only) in Table 5. The results showed the most effective interaction between the anti-bonding electrons of carbon $\left(\mathrm{C}_{4}-\mathrm{C}_{5}\right)$ and carbon $\left(\mathrm{C}_{1}-\mathrm{C}_{6}\right)$ of the $\pi$-conjugated system of the benzene ring. The results showed that the major interaction energies of this compound appeared from the interaction between the lone pair electrons of the $\mathrm{O}$ atom and antibonding orbitals of carbon atoms of the two carboxylate ions as well as sodium ions. There is also a significant

Table 5. Second order perturbation theory analysis of Fock matrix in NBO for the $\mathrm{Na}_{2}$ ATA and $\mathrm{Na}_{4} \mathrm{ATA}$ in gas phase ${ }^{\mathrm{a}}$.

\begin{tabular}{|c|c|c|c|c|c|c|c|}
\hline \multirow{2}{*}{$\begin{array}{c}\text { Complex } \\
\begin{array}{c}\text { Donor(i)-Acceptor(j) } \\
\text { Interaction }\end{array}\end{array}$} & \multicolumn{3}{|c|}{$\mathrm{Na}_{2} \mathrm{ATA}$} & \multicolumn{4}{|c|}{$\mathrm{Na}_{4} \mathrm{ATA}$} \\
\hline & $\begin{array}{c}E^{2} \\
(\mathrm{~kJ} / \mathrm{mol})\end{array}$ & $\begin{array}{l}E_{f} E_{i} \\
\text { (a.u.) }\end{array}$ & $F_{i j}$ (a.u.) & $\begin{array}{l}\text { Donor }(\mathrm{i}) \text {-Acceptor }(\mathrm{j}) \\
\text { Interaction }\end{array}$ & $\begin{array}{c}E^{2} \\
(\mathrm{~kJ} / \mathrm{mol})\end{array}$ & $\begin{array}{l}E_{f} E_{i} \\
\text { (a.u.) }\end{array}$ & $F_{i j}$ (a.u.) \\
\hline $\mathrm{LP}_{\mathrm{O} 10} \rightarrow \mathrm{LP}_{\mathrm{C} 4-\mathrm{CS}}^{*}$ & 65.65 & 0.72 & 0.096 & $\mathrm{LP}_{\mathrm{O} 10} \rightarrow \mathrm{BD}_{\mathrm{C} 4-\mathrm{O} 11}^{*}$ & 83.55 & 0.75 & 0.111 \\
\hline $\mathrm{LP}_{\mathrm{O} 10} \rightarrow \mathrm{LP}_{\mathrm{C} 9}^{*}$ & 722.91 & 0.15 & 0.158 & $\mathrm{LP}_{\mathrm{O} 11} \rightarrow \mathrm{BD}_{\mathrm{c9-010}}^{*}$ & 304.51 & 0.30 & 0.132 \\
\hline $\mathrm{LP}_{\mathrm{o} 11} \rightarrow \mathrm{LP}_{\mathrm{c} 9}^{*}$ & 617.35 & 0.15 & 0.152 & $\mathrm{LP}_{\mathrm{O} 13} \rightarrow \mathrm{BD}_{\mathrm{C} 12-014}^{*}$ & 283.55 & 0.31 & 0.130 \\
\hline $\mathrm{LP}_{\mathrm{O} 13} \rightarrow \mathrm{LP}_{\mathrm{C} 12}^{*}$ & 720.36 & 0.15 & 0.158 & $\mathrm{LP}_{\mathrm{O} 14} \rightarrow \mathrm{BD}_{\mathrm{C} 12-013}^{*}$ & 84.35 & 0.75 & 0.111 \\
\hline $\mathrm{LP}_{\mathrm{O} 14} \rightarrow \mathrm{LP}_{\mathrm{C} 12}^{*}$ & 710.61 & 0.15 & 0.158 & $\mathrm{LP}_{\mathrm{N} 16} \rightarrow \mathrm{BD}_{\mathrm{C} 4-05}^{*}$ & 69.16 & 0.38 & 0.077 \\
\hline $\mathrm{LP}_{\mathrm{O} 10}^{*} \rightarrow \mathrm{LP}_{\mathrm{Na} 12}^{*}$ & 16.07 & 0.76 & 0.006 & $\mathrm{BD}_{\mathrm{C} 4-\mathrm{CS}}^{*} \rightarrow \mathrm{BD}_{\mathrm{C} 1-\mathrm{C6}}^{*}$ & 1270.14 & 0.01 & 0.083 \\
\hline $\mathrm{LP}_{\mathrm{o} 11} \rightarrow \mathrm{LP}_{\mathrm{N} 12}^{*}$ & 16.23 & 0.79 & 0.050 & $\mathrm{LP}_{\mathrm{O} 13} \rightarrow \mathrm{LP}_{\mathrm{C} 12}^{*}$ & 648.02 & 0.16 & 0.158 \\
\hline $\mathrm{LP}_{\mathrm{O} 13}^{*} \rightarrow \mathrm{LP}_{\mathrm{N} 220}^{*}$ & 15.10 & 0.76 & 0.047 & $\mathrm{LP}_{\mathrm{O} 14} \rightarrow \mathrm{LP}_{\mathrm{C} 12}^{*}$ & 656.80 & 0.16 & 0.158 \\
\hline \multirow[t]{4}{*}{$\mathrm{LP}_{\mathrm{O} 14}^{*} \rightarrow \mathrm{LP}_{\mathrm{N} 20}^{*}$} & 15.10 & 0.76 & 0.047 & $\mathrm{LP}_{\mathrm{O} 10}^{*} \rightarrow \mathrm{LP}_{\mathrm{N} a 19}^{*}$ & 13.68 & 0.82 & 0.046 \\
\hline & & & & $\mathrm{LP}_{\mathrm{O} 11} \rightarrow \mathrm{LP}_{\mathrm{Na} 21}^{*}$ & 19.33 & 0.84 & 0.056 \\
\hline & & & & $\mathrm{LP}_{\mathrm{O} 13}^{*} \rightarrow \mathrm{LP}_{\mathrm{Na} 20}^{*}$ & 14.94 & 0.81 & 0.048 \\
\hline & & & & $\mathrm{LP}_{\mathrm{O} 14}^{*} \rightarrow \mathrm{LP}_{\mathrm{Na} 22}^{*}$ & 13.56 & 0.83 & 0.046 \\
\hline
\end{tabular}

[a] $\mathrm{LP}=$ lone pair, $\mathrm{LP}^{*}=$ antibonding lone pair, $\mathrm{BD}=$ bonding pair, $\mathrm{BD}^{*}=$ antibonding. 
interaction noticed with the lone pair electrons of nitrogen (amino group) to the anti-bonding of $\mathrm{C}_{4}-\mathrm{O}_{5}$.

\subsection{Electronic Properties and UV-Visible Spectrum of $\mathrm{H}_{2} \mathrm{ATA}$, $\mathrm{Na}_{2} \mathrm{ATA}$ and Sodium Inserted Complexes}

The time-dependent DFT (TD-DFT) on electronic absorption spectrum of $\mathrm{H}_{2}$ ATA, $\mathrm{Na}_{2} \mathrm{ATA}, \mathrm{Na}_{3} \mathrm{ATA}$ and $\mathrm{Na}_{4} \mathrm{ATA}$ in gas phase were calculated using B3LYP/6-311++G(d,p) method. The major possible transitions, calculated frontier orbital energies, oscillator strengths $(f)$, excitation energies $(\mathrm{eV})$ and molecular orbital (MO) major contributions listed in Table 6 and Table 7 respectively. The energy gap between the orbitals demonstrated the molecular chemical stability which is critical parameters in determining the molecular electrical

Table 6. Calculated wavelengths $(\lambda)$, oscillator strengths $(f)$ and excitation energies $(E)$ of $\mathrm{H}_{2} \mathrm{ATA}, \mathrm{Na}_{2} \mathrm{ATA}, \mathrm{Na}_{3} \mathrm{ATA}$ and $\mathrm{Na}_{4} \mathrm{ATA}$ at gas phase using TD-DFT/B3LYP/6-311++G(d,p) level of theory.

\begin{tabular}{|c|c|c|c|c|c|}
\hline Complex & $\lambda(\mathrm{nm})$ & $E(\mathrm{eV})$ & $\begin{array}{c}f \text { (Oscillator } \\
\text { Strengths) }\end{array}$ & MO Contributions & Assignments \\
\hline \multirow{5}{*}{$\mathrm{H}_{2} \mathrm{ATA}$} & 225 & 5.52 & 0.3977 & $\mathrm{H} \rightarrow \mathrm{L}+1(56 \%), \mathrm{H}-1 \rightarrow \mathrm{L}(16 \%)$ & $\operatorname{LLCT}\left(\pi \rightarrow \pi^{*}\right)$ \\
\hline & 255 & 4.87 & 0.1297 & $\mathrm{H}-1 \rightarrow \mathrm{L}(73 \%), \mathrm{H} \rightarrow \mathrm{L}+1(25 \%)$ & $\operatorname{LLCT}\left(\pi \rightarrow \pi^{*}\right)$ \\
\hline & 260 & 4.76 & 0.0000 & $\mathrm{H}-3 \rightarrow \mathrm{L}(90 \%), \mathrm{H}-2 \rightarrow \mathrm{L}(4 \%)$ & $\operatorname{LLCT}\left(\pi \rightarrow \pi^{*}\right)$ \\
\hline & 270 & 4.59 & 0.0000 & $\mathrm{H}-2 \rightarrow \mathrm{L}(91 \%), \mathrm{H}-3 \rightarrow \mathrm{L}(4 \%)$ & $\operatorname{LLCT}\left(\pi \rightarrow \pi^{\star}\right)$ \\
\hline & 365 & 3.39 & 0.0869 & $\mathrm{H} \rightarrow \mathrm{L}(98 \%), \mathrm{H}-1 \rightarrow \mathrm{L}+1(2 \%)$ & $\operatorname{LLCT}\left(\mathrm{n} \rightarrow \pi^{*}\right)$ \\
\hline \multirow{6}{*}{$\mathrm{Na}_{2} \mathrm{ATA}$} & 260 & 4.76 & 0.1396 & $\mathrm{H}-3 \rightarrow \mathrm{L}+2(46 \%), \mathrm{H}-3 \rightarrow \mathrm{L}+1(16 \%)$ & $\operatorname{LLCT}\left(\pi \rightarrow \pi^{*}\right)$ \\
\hline & 267 & 4.64 & 0.2047 & $\mathrm{H}-3 \rightarrow \mathrm{L}+1(55 \%), \mathrm{H}-6 \rightarrow \mathrm{L}+1(32 \%)$ & $\operatorname{LLCT}\left(\pi \rightarrow \pi^{*}\right)$ \\
\hline & 272 & 4.55 & 0.0030 & $\mathrm{H} \rightarrow \mathrm{L}+5(55 \%), \mathrm{H} \rightarrow \mathrm{L}+6(40 \%)$ & $\operatorname{LLCT}\left(\pi \rightarrow \pi^{*}\right)$ \\
\hline & 278 & 4.46 & 0.0026 & $\mathrm{H} \rightarrow \mathrm{L}+3(70 \%), \mathrm{H} \rightarrow \mathrm{L}+4(24 \%)$ & $\operatorname{LLCT}\left(\pi \rightarrow \pi^{*}\right)$ \\
\hline & 285 & 4.35 & 0.0029 & $\mathrm{H} \rightarrow \mathrm{L}+3(21 \%), \mathrm{H} \rightarrow \mathrm{L}+4(50 \%)$ & $\operatorname{LLCT}\left(\pi \rightarrow \pi^{*}\right)$ \\
\hline & 340 & 3.65 & 0.0989 & $\mathrm{H} \rightarrow \mathrm{L}+2(96)$ & $\operatorname{LLCT}\left(\mathrm{n} \rightarrow \pi^{*}\right)$ \\
\hline \multirow{6}{*}{$\mathrm{Na}_{3} \mathrm{ATA}$} & 235 & 5.28 & 0.0716 & $\mathrm{H}-5 \rightarrow \mathrm{L}+1(70 \%)$ & $\operatorname{LLCT}\left(\pi \rightarrow \pi^{\star}\right)$ \\
\hline & 251 & 4.93 & 0.0091 & $\mathrm{H} \rightarrow \mathrm{L}+3(73 \%)$ & $\operatorname{LLCT}\left(\pi \rightarrow \pi^{*}\right)$ \\
\hline & 255 & 4.87 & 0.2060 & $\mathrm{H}-5 \rightarrow \mathrm{L}+1(10 \%), \mathrm{H}-3 \rightarrow \mathrm{L}+1(41 \%)$ & $\operatorname{LLCT}\left(\pi \rightarrow \pi^{*}\right)$ \\
\hline & 265 & 4.68 & 0.0252 & $\mathrm{H}-2 \rightarrow \mathrm{L}+1(71 \%), \mathrm{H} \rightarrow \mathrm{L}+3(18 \%)$ & $\operatorname{LLCT}\left(\pi \rightarrow \pi^{*}\right)$ \\
\hline & 288 & 4.31 & 0.0416 & $\mathrm{H}-1 \rightarrow \mathrm{L}+1(88 \%)$ & $\operatorname{LLCT}\left(\pi \rightarrow \pi^{\star}\right)$ \\
\hline & 307 & 4.03 & 0.0066 & $\mathrm{H}-1 \rightarrow \mathrm{L}(89 \%)$ & $\operatorname{LLCT}\left(\pi \rightarrow \pi^{*}\right)$ \\
\hline \multirow{7}{*}{$\mathrm{Na}_{4} \mathrm{ATA}$} & 185 & 6.71 & 0.1024 & $\mathrm{H}-4 \rightarrow \mathrm{L}+1(20 \%), \mathrm{H}-1 \rightarrow \mathrm{L}+5(10 \%)$ & $\operatorname{LLCT}\left(\pi \rightarrow \pi^{*}\right)$ \\
\hline & 193 & 6.43 & 0.2045 & $\mathrm{H}-1 \rightarrow \mathrm{L}+5(52 \%)$ & $\operatorname{LLCT}\left(\pi \rightarrow \pi^{*}\right)$ \\
\hline & 199 & 6.22 & 0.4060 & $\mathrm{H}-1 \rightarrow \mathrm{L}+1(13 \%), \mathrm{H} \rightarrow \mathrm{L}+5(37 \%)$ & $\operatorname{LLCT}\left(\pi \rightarrow \pi^{*}\right)$ \\
\hline & 219 & 5.66 & 0.0829 & $\mathrm{H}-3 \rightarrow \mathrm{L}(10 \%), \mathrm{H}-3 \rightarrow \mathrm{L}+1(33 \%)$ & $\operatorname{LLCT}\left(\pi \rightarrow \pi^{*}\right)$ \\
\hline & 228 & 5.43 & 0.0824 & $\mathrm{H} \rightarrow \mathrm{L}(51 \%), \mathrm{H}-3 \rightarrow \mathrm{L}+1(10 \%)$ & $\operatorname{LLCT}\left(\pi \rightarrow \pi^{*}\right)$ \\
\hline & 245 & 5.07 & 0.1268 & $\mathrm{H}-1 \rightarrow \mathrm{L}(17 \%), \mathrm{H}-1 \rightarrow \mathrm{L}+1(47 \%)$ & $\operatorname{LLCT}\left(\pi \rightarrow \pi^{*}\right)$ \\
\hline & 267 & 4.65 & 0.0523 & $\mathrm{H} \rightarrow \mathrm{L}(17 \%), \mathrm{H} \rightarrow \mathrm{L}+1(64 \%)$ & $\operatorname{LLCT}\left(\pi \rightarrow \pi^{*}\right)$ \\
\hline
\end{tabular}


Table 7. Frontier molecular orbital energetic parameters of free $\mathrm{H}_{2} \mathrm{ATA}, \mathrm{Na}_{2} \mathrm{ATA}$, $\mathrm{Na}_{3} \mathrm{ATA}$ and $\mathrm{Na}_{4} \mathrm{ATA}$ at gaseous state .

\begin{tabular}{cccccc}
\hline Complex & $E_{\text {Номо }}(\mathrm{eV})$ & $E_{\mathrm{LUMO}}(\mathrm{eV})$ & $\Delta E_{\text {gap }}(\mathrm{eV})$ & $\mathrm{I}(\mathrm{eV})$ & $\mathrm{A}(\mathrm{eV})$ \\
\hline $\mathrm{H}_{2} \mathrm{ATA}$ & -6.24 & -2.38 & 3.86 & 6.24 & 2.38 \\
$\mathrm{Na}_{2} \mathrm{ATA}$ & -4.79 & -1.47 & 3.32 & 4.79 & 1.47 \\
$\mathrm{Na}_{3} \mathrm{ATA}$ & -8.90 & -4.35 & 4.55 & 8.90 & 4.35 \\
$\mathrm{Na}_{4} \mathrm{ATA}$ & -12.02 & -7.03 & 4.99 & 12.02 & 7.03 \\
\hline
\end{tabular}

[a] $\Delta E_{\text {gap }}=$ Energy gap, $\mathrm{I}=$ ionization potential, $\mathrm{A}=$ electron affinity.

transport properties owing to electron conductivity [47]. The chemical and spectroscopic properties of the molecules are mainly depending on the energy gaps. The frontier molecular orbitals show the electron density for predicting the most reactive position in $\pi$-electron systems and also explain several types of reaction in conjugated system [48]. The frontier molecular orbitals (HOMO and LUMO) of free $\mathrm{H}_{2} \mathrm{ATA}$ are shown in Figure 6. In free $\mathrm{H}_{2} \mathrm{ATA}$ molecule, the LLCT (Ligand to ligand charge transfer) bands are mainly observed at $185 \mathrm{~nm}$, $224 \mathrm{~nm}$ and $365 \mathrm{~nm}$ indicating $\pi \rightarrow \pi^{*}$ and $\mathrm{n} \rightarrow \pi^{\star}$ transitions. However, TD-DFT data demonstrated that LLCT bands appeared at $185-224 \mathrm{~nm}$. The sharp band appeared at $\sim 224 \mathrm{~nm}$. The molecular orbital contribution (56\%) at this band in the gas phase showed the major transitions occurred between the highest occupied molecular orbital (HOMO) to lowest unoccupied molecular orbital+1 $(\mathrm{LUMO}+1)$ and the energy gap between HOMO and LUMO+1 was $5.52 \mathrm{eV}$ for $\mathrm{H}_{2}$ ATA. An electronic system with a larger HOMO-LUMO gap should be less reactive than one having a smaller gap. The HOMO-LUMO $\left(\Delta \mathrm{E}_{\text {gap }}\right)$ gap of the present studied molecule $\mathrm{H}_{2} \mathrm{ATA}$ is $3.86 \mathrm{eV}$ (Figure 6), indicating the high reactivity. Whereas in the metal complexes, $\mathrm{Na}_{2} \mathrm{ATA}$ and $\mathrm{Na}_{4} \mathrm{ATA}$, the major transitions occur at $267 \mathrm{~nm}$ and $199 \mathrm{~nm}$, respectively, due to LLCT ( $\pi \rightarrow \pi^{*}$ ) transition. The molecular contribution (55\%) at $267 \mathrm{~nm}$ band for $\mathrm{Na}_{2} \mathrm{ATA}$ exhibited the major transitions occurred between the highest molecular orbital-3 (HOMO-3) to lowest unoccupied molecular orbital+1 (LUMO+1).

\subsection{Global Reactivity Descriptors of $\mathrm{H}_{2} \mathrm{ATA}, \mathrm{Na}_{2} \mathrm{ATA}$ and Its Sodium Inserted Complexes ( $\mathrm{Na}_{3} \mathrm{ATA}$ and $\left.\mathrm{Na}_{4} \mathrm{ATA}\right)$}

The global reactivity descriptors, e.g. electronegativity $(\chi)$, chemical potential $(\mu)$, global hardness $(\eta)$, global softness $(\mathrm{s})$, electrophilicity index $(\omega)$ were determined by the conceptual density functional theory on the basis of Koopmans's theorem [49]. The global reactivity descriptors of the titled molecule and its sodium salts were calculated. Global reactivity descriptors were calculated using the energies of frontier molecular orbitals $\mathrm{E}_{\mathrm{HOMO}}$ and $\mathrm{E}_{\mathrm{LUMO}}$ as $\chi=$ $-1 / 2\left(\mathrm{E}_{\mathrm{LUMO}}+\mathrm{E}_{\text {номо }}\right), \mu=-\chi=1 / 2\left(\mathrm{E}_{\mathrm{LUMO}}+\mathrm{E}_{\text {Номо }}\right), \eta=1 / 2\left(\mathrm{E}_{\mathrm{LUMO}}-\mathrm{E}_{\text {Hомо }}\right), \mathrm{s}=$ $1 / 2 \eta$ and $\omega=\mu^{2} / 2 \eta$. The energies of frontier molecular orbitals, ( $\mathrm{E}_{\mathrm{LUMO}}$ and $\mathrm{E}_{\text {номо }}$ ) and global reactivity descriptors of $\mathrm{H}_{2} \mathrm{ATA} \mathrm{Na}_{2} \mathrm{ATA}, \mathrm{Na}_{3} \mathrm{ATA}$ and $\mathrm{Na}_{4}$ ATA are listed in Table 6 and Table 7. The studied molecules, $\mathrm{H}_{2} \mathrm{ATA}$ and 


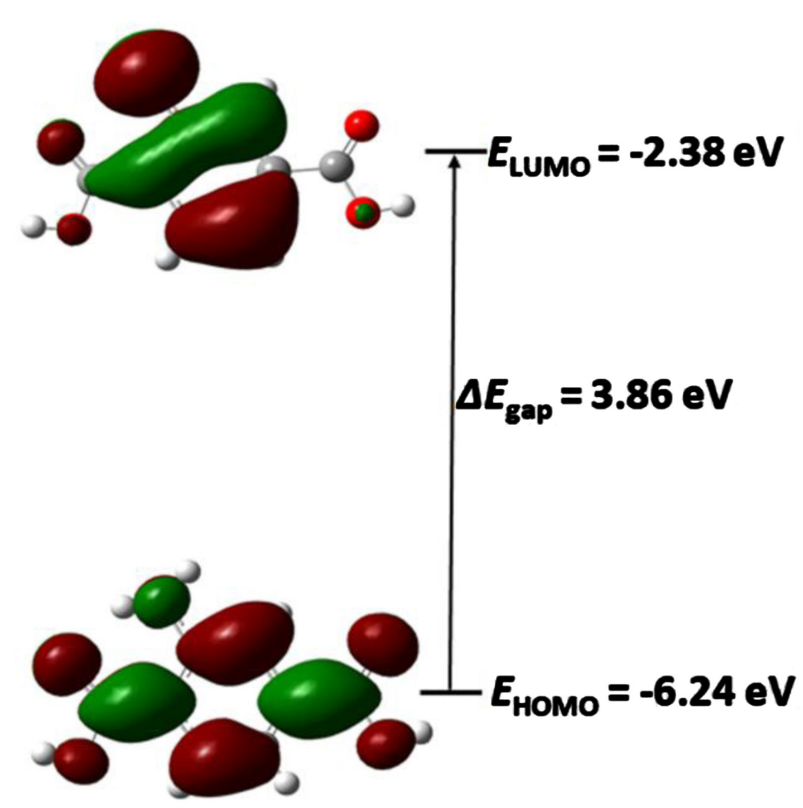

Figure 6. The frontier molecular orbitals (HOMO and LUMO) of $\mathrm{H}_{2}$ ATA.

Table 8. Quantum chemical descriptors of free $\mathrm{H}_{2} \mathrm{ATA}, \mathrm{Na}_{2} \mathrm{ATA}, \mathrm{Na}_{3} \mathrm{ATA}$ and $\mathrm{Na}_{4} \mathrm{ATA}^{\mathrm{a}}$.

\begin{tabular}{cccccc}
\hline Complex & $\chi(\mathrm{eV})$ & $\mu(\mathrm{eV})$ & $\eta(\mathrm{eV})$ & $\mathrm{s}(\mathrm{eV})$ & $\omega(\mathrm{eV})$ \\
\hline $\mathrm{H}_{2}$ ATA & 4.310 & -4.310 & 1.930 & 0.259 & 4.81 \\
$\mathrm{Na}_{2}$ ATA & 3.130 & -3.130 & 1.662 & 0.301 & 2.95 \\
$\mathrm{Na}_{3}$ ATA & 6.625 & -6.625 & 2.275 & 0.219 & 9.65 \\
$\mathrm{Na}_{4}$ ATA & 9.525 & -9.525 & 2.495 & 0.200 & 18.18
\end{tabular}

[a] $\chi=$ electronegativity, $\mu=$ chemical potential, $\eta=$ global hardness, $s=$ global softness, $\omega=$ electrophilicity index.

$\mathrm{Na}_{2} \mathrm{ATA}$ showed a higher HOMO-LUMO gap in gas phase signifying harder molecule. The free $\mathrm{H}_{2} \mathrm{ATA}$ exhibited higher value for global electrophilicity index, hardnessand electronegativity than $\mathrm{Na}_{2} \mathrm{ATA}$ (Table 8).

\section{Conclusion}

In summary, we investigated the structural and vibrational properties of 2-aminoterephthalic acid, disodium 2-aminoterephthalate and inserted sodium complexes using density functional theory (DFT/B3LYP) methods with 6-311++ $\mathrm{G}(\mathrm{d}, \mathrm{p})$ basis set. The calculated binding energy, enthalpy and Gibbs free energy of $\mathrm{Na}_{2} \mathrm{ATA}$ revealed that this compound is thermodynamically more stable than other inserted sodium complexes such as $\mathrm{Na}_{3} \mathrm{ATA}$ or $\mathrm{Na}_{4} \mathrm{ATA}$. $\mathrm{NBO}$ analysis of disodium 2-aminoterephthalate exhibited the major interaction energy of the $\mathrm{O}$ atom with the carbon atoms of the two carboxylate ions as well as its sodium ions. The UV-visible spectrum of the 2-aminoterephthalic acid indicated that molecular orbital contribution (56\%) occurred between the highest occupied molecular orbital (HOMO) and the lowest unoccupied molecular orbital+1 
(LUMO+1), whereas, in the case of disodium salt, molecular orbital contribution (55\%) occurred between the highest molecular orbital-3 (HOMO-3) and lowest unoccupied molecular orbital+1 (LUMO+1). In terms of the global reactivity descriptors, $\mathrm{H}_{2} \mathrm{ATA}$ showed higher electronegativity than $\mathrm{Na}_{2} \mathrm{ATA}$. The present computational study of the 2-aminoterephthalic acid and its sodium salts provide strong encouragement for future exploration of functionalized terephthalic acid derivatives as useful material for the safe, low cost, non-toxic, green and easy technology for the production of sodium ion batteries for industrial application.

\section{Acknowledgements}

Financial support of this work by the Centre for Advanced Research in Sciences (University of Dhaka, Dhaka, Bangladesh) is greatly appreciated.

\section{Conflicts of Interest}

The authors declare no conflicts of interest regarding the publication of this paper.

\section{References}

[1] Qi, W., Shapter, J.G., Wu, Q., Yin, T., Gao, G. and Cui, D. (2017) Nanostructured Anode Materials for Lithium-Ion Batteries: Principal, Recent Progress and Future Perspectives. Journal of Materials Chemistry A, 5, 19521-19540. https://doi.org/10.1039/C7TA05283A

[2] Wang, L.P., Yu, L., Wang, X., Srinivasan, M. and Xu, Z.J. (2015) Recent Developments in Electrode Materials for Sodium-Ion Batteries. Journal of Materials Chemistry $A$, 3, 9353-9378. https://doi.org/10.1039/C4TA06467D

[3] Hwang, J.-Y., Myung, S.-T. and Sun, Y.-K. (2017) Sodium-Ion Batteries: Present and Future. Chemical Society Reviews, 46, 3529-3614.

https://doi.org/10.1039/C6CS00776G

[4] Huang, Y., Zheng, Y., Li, X., Adams, F., Luo, W., Huang, Y. and Hu, L. (2018) Electrode Materials of Sodium-Ion Batteries toward Practical Application. ACS Energy Letters, 3, 1604-1612. https://doi.org/10.1021/acsenergylett.8b00609

[5] Lee, K.T., Ramesh, T.N., Nan, F., Botton, G. and Nazar, L.F. (2011) Topochemical Synthesis of Sodium Metal Phosphate Olivines for Sodium-Ion Batteries. Chemistry of Materials, 23, 3593-3600. https://doi.org/10.1021/cm200450y

[6] Lu, Y., Wang, L., Cheng, J. and Goodenough, J.B. (2012) Prussian Blue: A New Framework of Electrode Materials for Sodium Batteries. Chemical Communications, 48, 6544-6546. https://doi.org/10.1039/c2cc31777j

[7] Jian, Z., Han, W., Lu, X., Yang, H., Hu, Y.-S., Zhou, J., Zhou, Z., Li, J., Chen, W., Chen, D. and Chen, L. (2013) Superior Electrochemical Performance and Storage Mechanism of $\mathrm{Na}_{3} \mathrm{~V}_{2}\left(\mathrm{PO}_{4}\right)_{3}$ Cathode for Room-Temperature Sodium-Ion Batteries. Advanced Energy Materials, 3, 156-160. https://doi.org/10.1002/aenm.201200558

[8] Ramasamy, H.V., Kaliyappan, K., Thangavel, R., Aravindan, V., Kang, K., Kim, D.U., Park, Y., Sun, X. and Lee, Y.-S. (2017) Cu-Doped $\mathrm{P}_{2}-\mathrm{Na}_{0.5} \mathrm{Ni}_{0.33} \mathrm{Mn}_{0.67} \mathrm{O}_{2}$ Encapsulated with $\mathrm{MgO}$ as a Novel High Voltage Cathode with Enhanced Na-Storage Properties. Journal of materials Chemistry A, 5, 8408-8415. 
https://doi.org/10.1039/C6TA10334K

[9] Park, J.-K., Park, G.-G., Kwak, H.H., Hong, S.-T. and Lee, J.-W. (2018) Enhanced Rate Capability and Cycle Performance of Titanium-Substituted P2-Type $\mathrm{Na}_{0.67} \mathrm{Fe}_{0.5} \mathrm{Mn}_{0.5} \mathrm{O}_{2}$ as a Cathode for Sodium-Ion Batteries. ACS Omega, 3, 361-368. https://doi.org/10.1021/acsomega.7b01481

[10] Tang, K., Fu, L., White, R.J., Yu, L., Titirici, M.-M., Antonietti, M. and Maier, J. (2012) Hollow Carbon Nanospheres with Superior Rate Capability for Sodium-Based Batteries. Advanced Energy Materials, 2, 873-877. https://doi.org/10.1002/aenm.201100691

[11] Wang, Y.-X., Chou, S.-L., Liu, H.-K. and Dou, S.-X. (2013) Reduced Graphene Oxide with Superior Cycling Stability and Rate Capability for Sodium Storage. Carbon, 57, 202-208. https://doi.org/10.1016/j.carbon.2013.01.064

[12] Ding, J., Wang, H., Li, Z., Kohandehghan, A., Cui, K., Xu, Z., Zahiri, B., Tan, X., Lotfabad, E.M., Olsen, B.C. and Mitlin, D. (2013) Carbon Nanosheet Frameworks Derived from Peat Moss as High Performance Sodium Ion Battery Anodes. ACS Nano, 7, 11004-11015. https://doi.org/10.1021/nn404640c

[13] Kim, Y., Park, Y., Choi, A., Choi, N.-S., Kim, J., Lee, J., Ryu, J.H., Oh, S.M. and Lee, K.T. (2013) An Amorphous Red Phosphorus/Carbon Composite as a Promising Anode Material for Sodium Ion Batteries. Advanced Materials, 25, 3045-3049. https://doi.org/10.1002/adma.201204877

[14] Zhou, X. and Guo, Y.-G. (2014) Highly Disordered Carbon as a Superior Anode Material for Room-Temaperature Sodium-Ion Batteries. ChemElectroChem, 1, 83-86. https://doi.org/10.1002/celc.201300071

[15] Chen, C., Wen, Y., Hu, X., Ji, X., Yan, M., Mai, L., Hu, P., Shan, B. and Huang, Y. (2015) $\mathrm{Na}(+)$ Intercalation Pseudocapacitance in Graphene-Coupled Titanium Oxide Enabling Ultra-Fast Sodium Storage and Long-Term Cycling. Nature Communications, 6, Article No. 6929. https://doi.org/10.1038/ncomms7929

[16] Chen, K.-Y., Zhang, W.-X., Liu, Y., Zhu, H.-P., Duan, J., Xiang, X.-H., Xue, L.-H. and Huang, Y.-H. (2015) Carbon Coated K(0.8)Ti(1.73)Li(0.27)O4: A Novel Anode Material for Sodium-Ion Batteries with a Long Cycle Life. Chemical Communications, 51, 1608-1611. https://doi.org/10.1039/C4CC08051C

[17] Hung, T.-F., Lan, W.-H., Yeh, Y.-W., Chang, W.-S., Yang, C.-C. and Lin, J.-C. (2016) Hydrothermal Synthesis of Sodium Titanium Phosphate Nanoparticles as Efficient Anode Materials for Aqueous Sodium-Ion Batteries. ACS Sustainable Chemistry \& Engineering, 4, 7074-7079. https://doi.org/10.1021/acssuschemeng.6b01962

[18] Nyström, G., Razaq, A., Stromme, M., Nyholm, L. and Mihranyan, A. (2009) Ultrafast All-Polymer Paper-Based Batteries. Nano Letters, 9, 3635-3639.

https://doi.org/10.1021/nl901852h

[19] Chen, J. and Cheng, F.Y. (2009) Combination of Lightweight Elements and Nanostructured Materials for Batteries. Accounts of Chemical Research, 42, 713-723. https://doi.org/10.1021/ar800229g

[20] Pan, L.J., Yu, G.H., Zhai, D.Y., Lee, H.R., Zhao, W.T., Liu, N., Wang, H.L., Tee, B.C.K., Shi, Y., Cui, Y. and Bao, Z.N. (2012) Hierarchical Nanostructured Conducting Polymer Hydrogel with High Electrochemical Activity. Proceedings of the National Academy of Sciences of the United States of America, 109, 9287-9292. https://doi.org/10.1073/pnas.1202636109

[21] Wu, H., Yu, G., Pan, L., Liu, N., McDowell, M.T., Bao, Z. and Cui, Y. (2013) Stable Li-Ion Battery Anodes by In-Situ Polymerization of Conducting Hydrogel to Con- 
formally Coat Silicon Nanoparticles. Nature Communications, 4, Article No. 1943. https://doi.org/10.1038/ncomms2941

[22] Wang, S., Wang, L., Zhang, K., Zhu, Z., Tao, Z. and Chen, J. (2013) Organic $\mathrm{Li}_{4} \mathrm{C}_{8} \mathrm{H}_{2} \mathrm{O}_{6}$ Nanosheets for Lithium-Ion Batteries. Nano Letters, 13, 4404-4409. https://doi.org/10.1021/nl402239p

[23] Wang, S., Wang, L., Zhu, Z., Hu, Z., Zhao, Q. and Chen, J. (2014) All Organic Sodium-Ion Batteries with $\mathrm{Na}_{4} \mathrm{C}_{8} \mathrm{H}_{2} \mathrm{O}_{6}$. Angewandte Chemie International Edition, 53, 5892-5896. https://doi.org/10.1002/anie.201400032

[24] Park, Y., Shin, D.-S., Woo, S.H., Choi, N.S., Shin, K.H., Oh, S.M., Lee, K.T. and Hong, S.Y. (2012) Sodium Terephthalate as an Organic Anode Material for Sodium Ion Batteries. Advanced Materials, 24, 3562-3567.

https://doi.org/10.1002/adma.201201205

[25] Han, M.H., Gonzalo, E., Singh, G. and Rojo, T. (2015) A Comprehensive Review of Sodium Layered Oxides: Powerful Cathodes for Na-Ion Batteries. Energy \& Environmental Science, 8, 81-102. https://doi.org/10.1039/C4EE03192J

[26] Mayo, M., Griffith, K.J., Pickard, C.J. and Morris, A.J. (2016) Ab Initio Study of Phosphorus Anodes for Lithium- and Sodium-Ion Batteries. Chemistry of Materials, 28, 2011-2021. https://doi.org/10.1021/acs.chemmater.5b04208

[27] Stratford, J.M., Mayo, M., Allan, P.K., Pecher, O., Borkiewicz, O.J., Wiaderek, K.M., Chapman, K.W., Pickard, C.J., Morris, A.J. and Grey, C.P. (2017) Investigating Sodium Storage Mechanisms in Tin Anodes: A Combined Pair Distribution Function Analysis, Density Functional Theory, and Solid-State NMR Approach. Journal of the American Chemical Society, 139, 7273-7286. https://doi.org/10.1021/jacs.7b01398

[28] Li, J., Yan, D., Lu, T., Qin, W., Yao, Y. and Pan, L. (2017) Significantly Improved Sodium-Ion Storage Performance of CuS Nanosheets Anchored into Reduced Graphene Oxide with Ether-Based Electrolyte. ACS Applied Materials \& Interfaces, 9 , 2309-2316. https://doi.org/10.1021/acsami.6b12529

[29] Eddaoudi, M., Kim, J., Rosi, N., Vodak, D., Wachter, J., O’Keeffe, M. and Yaghi, O.M. (2002) Systematic Design of Pore Size and Functionality in Isoreticular MOFs and Their Application in Methane Storage. Science, 295, 469-472. https://doi.org/10.1126/science.1067208

[30] Rowsell, J.L.C. and Yaghi, O.M. (2006) Effects of Functionalization, Catenation, and Variation of the Metal Oxide and Organic Linking Units on the Low-Pressure Hydrogen Adsorption Properties of Metal-Organic Frameworks. Journal of the American Chemical Society, 128, 1304-1315. https://doi.org/10.1021/ja056639q

[31] Bhattacharjee, S., Yang, D.-A. and Ahn, W.-S. (2011) A New Heterogeneous Catalyst for Epoxidation of Alkenesvia One-Step Post-Functionalization of IRMOF-3 with a Manganese (II) Acetylacetonate Complex. Chemical Communications, 47, 3637-3639. https://doi.org/10.1039/c1cc00069a

[32] Kim, J., McNamara, N.D., Her, T.H. and Hicks, J.C. (2013) Carbothermal Reduction of Ti-Modified IRMOF-3: An Adaptable Synthetic Method to Support Catalytic Nanoparticles on Carbon. ACS Applied Materials \& Interfaces, 5, 11479-11487. https://doi.org/10.1021/am404089v

[33] Rostamnia, S. and Xin, H. (2014) Basic Isoreticular Metal-Organic Framework (IRMOF-3) Porous Nanomaterial as a Suitable and Green Catalyst for Selective Unsymmetrical Hantzsch Coupling Reaction. Applied Organometallic Chemistry, 28, 359-363. https://doi.org/10.1002/aoc.3136

[34] Lee, Y.-R., Cho, S.-M., Ahn, W.-S., Lee, C.-H., Lee K.-H. and Cho, W.-S. (2015) Fa- 
cile Synthesis of an IRMOF-3 Membrane on Porous $\mathrm{Al}_{2} \mathrm{O}_{3}$ Substrate via a Sonochemical Route. Microporous and Mesoporous Materials, 213, 161-168. https://doi.org/10.1016/j.micromeso.2015.04.021

[35] Bhattacharjee, S. (2018) Synthesis and Application of Layered Double Hydroxide-Hosted 2-Aminoterephthalate for the Knoevenagel Condensation Reaction. Inorganic and Nano-Metal Chemistry, 48, 340-346. https://doi.org/10.1080/24701556.2019.1567538

[36] Britt, D., Tranchemontagne, D. and Yaghi, O.M. (2008) Metal-Organic Frameworks with High Capacity and Selectivity for Harmful Gases. Proceedings of the National Academy of Sciences of the United States of America, 105, 11623-11627. https://doi.org/10.1073/pnas.0804900105

[37] Karabacak, M., Cinar, M., Unal, Z. and Kurt, M. (2010) FT-IR, UV Spectroscopic and DFT Quantum Chemical Study on the Molecular Conformation, Vibrational and Electronic Transitions of 2-Aminoterephthalic Acid. Journal of Molecular Structure, 982, 22-27. https://doi.org/10.1016/j.molstruc.2010.07.033

[38] Renault, St., Oltean, V.A., Ebadi, M., Edström, K. and Brandell, D. (2017) Dilithium 2-Aminoterephthalate as a Negative Electrode Material for Lithium-Ion Batteries. Solid State Ionics, 307, 1-5. https://doi.org/10.1016/j.ssi.2017.05.005

[39] Becke, A.D. (1993) Density-Functional Thermochemistry. III. The Role of Exact Exchange. Journal of Chemical Physics, 98, 5648-5652. https://doi.org/10.1063/1.464913

[40] Matin, M.A., Chitumalla, R.K., Lim, M., Gao, X. and Jang, J.K. (2015) Density Functional Theory Study on the Cross-Linking of Mussel Adhesive Proteins. Journal of Physical Chemistry B, 119, 5496-5504. https://doi.org/10.1021/acs.jpcb.5b01152

[41] Frisch, M.J., Trucks, G.W., Schlegel, H.B., Scuseria, G.E., Robb, M.A., Cheeseman, J.R., Scalmani, G., Barone, V., Petersson, G.A., Nakatsuji, H., Li, X., Caricato, M., Marenich, A.V., Bloino, J., Janesko, B.G., Gomperts, R., Mennucci, B., Hratchian, H.P., Ortiz, J.V., Izmaylov, A.F., Sonnenberg, J.L., Williams-Young, D., Ding, F., Lipparini, F., Egidi, F., Goings, J., Peng, B., Petrone, A., Henderson, T., Ranasinghe, D., Zakrzewski, V.G., Gao, J., Rega, N., Zheng, G., Liang, W., Hada, M., Ehara, M., Toyota, K., Fukuda, R., Hasegawa, J., Ishida, M., Nakajima, T., Honda, Y., Kitao, O., Nakai, H., Vreven, T., Throssell, K., Montgomery, J.A., Peralta, J.E., Ogliaro, F., Bearpark, M.J., Heyd, J.J., Brothers, E.N., Kudin, K.N., Staroverov, V.N., Keith, T.A., Kobayashi, R., Normand, J., Raghavachari, K., Rendell, A.P., Burant, J.C., Iyengar, S.S., Tomasi, J., Cossi, M., Millam, J.M., Klene, M., Adamo, C., Cammi, R., Ochterski, J.W., Martin, R.L., Morokuma, K., Farkas, O., Foresman, J.B. and Fox, D.J. (2016) Gaussian 16, Revision B.01. Gaussian, Inc., Wallingford.

[42] Lakraychi, A.E., Dolhem, F., Djedaïni-Pilard, F., Thiam, A., Frayret, C. and Becuwe, M. (2017) Decreasing Redox Voltage of Terephthalate-Based Electrode Material for Li-Ion Battery Using Substituent Effect. Journal Power Sources, 359, 198-204. https://doi.org/10.1016/j.jpowsour.2017.05.046

[43] He, J., Zhang, Y., Yu, J., Pan, Q. and Xu, R. (2006) Two 2-D 36 Tessellated Metal-Organic Frameworks Constructed from Trimetallic Clusters and DicarboxylateDitopic Links. Materials Research Bulletin, 41, 925-933. https://doi.org/10.1016/j.materresbull.2006.01.018

[44] Garibay, S.J., Wang, Z. and Cohen, S.M. (2010) Evaluation of Heterogeneous Metal-Organic Framework Organocatalysts Prepared by Postsynthetic Modification. Inorganic Chemistry, 49, 8086-8091. https://doi.org/10.1021/ic1011549

[45] Liu, L.L., et al. (2012) Engineering Metal-Organic Frameworks Immobilize Gold 
Catalysts for Highly Efficient One-Pot Synthesis of Propargylamines. Green Chemistry, 14, 1710-1720. https://doi.org/10.1039/c2gc35284b

[46] Thompson, H.W. and Torkington, P. (1945) The Vibrational Spectra of Esters and Ketones. Journal of the Chemical Society, 171, 640-645. https://doi.org/10.1039/jr9450000640

[47] Fukui, K. (1982) Role of Frontier Orbitals in Chemical Reactions. Science, 218, 747-754. https://doi.org/10.1126/science.218.4574.747

[48] Fukui, K., Yonezawa, T. and Shingu, H. (1952) A Molecular Orbital Theory of Reactivity in Aromatic Hydrocarbons. The Journal of Chemical Physics, 20, 722-725. https://doi.org/10.1063/1.1700523

[49] Koopmans, T. (1934) Über Die Zuordnung Von Wellenfunktionen Und EigenwertenZu Den EinzelnenElektronenEines Atoms. Physica, 1, 104-113.

https://doi.org/10.1016/S0031-8914(34)90011-2 